\title{
Pelatihan Pembuatan Media Pembelajaran Berbasis AutoPlay bagi Kelompok Kerja Guru Kecamatan Geger di Kabupaten Bangkalan
}

\section{Training on Creating AutoPlay Based Learning Media for Teacher Working Groups in Geger District, Bangkalan Regency}

\author{
Buaddin Hasan*, Didik Hermanto
}

Prodi Pendidikan Matematika Sekolah Tinggi Keguruan dan Ilmu Pendidikan PGRI Bangkalan, Jl. Soekarno Hatta No. 52 Bangkalan, Jawa Timur, Indonesia

\begin{tabular}{l}
\hline Info Artikel \\
\hline Diterima 08 Nopember 2019 \\
Ditelaah 03 Desember 2019 \\
Disetujui 29 Desember 2019 \\
Tersedia daring 31 Desember \\
2019 \\
*Penulis untuk korespondensi \\
buaddinhasan@stkippgri- \\
bkl.ac.id
\end{tabular}

Kata Kunci:

Pengabdian,

Media interaktif,

AutoPlay

\section{Keywords:}

Community service,

AutoPlay
Interactive media,

\begin{abstract}
ABSTRAK
Media menjadi sarana yang sangat dibutuhkan oleh pendidik dalam rangka menciptakan suasana proses belajar yang maksimal. Dalam proses pembelajaran, guru sebaiknya menggunakan media interaktif sebagai media penyampaian informasi. Media dalam proses pembelajaran dimaksudkan untuk memudahkan guru dalam menyampaikan pesan, informasi, atau materi pelajaran kepada siswa. Program pengabdian ini mempunyai tujuan untuk meberikan pendampingan kepada guru dalam membuat media pembelajaran interaktif berbasis AutoPlay. Program pengabdian ini dilakukan dengan dua metode. Yang pertama adalah metode pendidikan masyarakat yaitu pelatihan dan pendampingan bagi guru dalam membuat media pembelajaran dengan berbagai aplikasi terutama AutoPlay. Metode pelatihan ini merupakan upaya mendidik dan melatih mitra agar mampu memanfaatkan komputer sehingga menghasilkan media pembelajaran yang menarik. Yang kedua adalah metode substitusi Ilmu Pengetahuan dan Teknologi yaitu memberikan gambaran cara pemanfaatan teknologi dalam membuat media pemebelajaran. Hasil pelaksanaan pengabdian ini adalah adanya peningkatan pengetahuan dan keterampilan guru yang mencapai $90 \%$ dari 20 orang yang mengikuti program pengabdian dalam membuat media pembelajaran interaktif berbasis AutoPlay. Rerata $80 \%$ guru mampu mengimplementasi media AutoPlay dalam proses pembelajaran. Penggunaan media AutoPlay dalam pembelajaran menjadikan siswa semakin termotivasi dalam belajar.
\end{abstract}

\section{ABSTRACT}

Media becomes a tool that is needed by educators to create a pleasant atmosphere of a learning process. In the learning process, teachers should use interactive media as a medium for delivering information. Media in the learning process is intended to facilitate the teacher in conveying messages, information, or subject matter to students. This service program was aimed to provide mentoring to teachers in creating interactive learning media based on AutoPlay. This service program is carried out by two methods. The first was the public education method, namely training and mentoring for teachers in creating learning media with various applications, especially AutoPlay. This training method was an effort to educate and train partners to be able to use computers to produce exciting learning media. The second was the substitution of a science-and-technology method, which provided an overview of how to use technology in making learning media. The result of the implementation of this service was an increase in the knowledge and skills of teachers, reaching $90 \%$ of the 20 teachers who participated in the service program. On average, $80 \%$ of teachers were able to implement AutoPlay media in the learning process. The use of AutoPlay media in learning made students more motivated in learning.

ISSN 2685-0354 (Media Online). Diterbitkan oleh Universitas Prof. Dr. Hazairin, SH. Ini merupakan jurnal bebas akses di bawah lisensi Creative Commons Atribution 4.0 International (https://creativecommons.org/licenses/by/4.0 


\section{PENDAHULUAN}

Banyak faktor yang mempengaruhi perkembangan dunia pendidikan pada saat ini. Salah satunya adalah kemajuan di bidang teknologi informasi yang sangat pesat dan kompetitif. Di era millennial pada saat ini, masyarakat termasuk para guru terkadang tidak didukung dengan pengetahuan dalam memanfaatkan teknologi. Pemanfaatan teknologi sangat dibutuhkan untuk pemberdayaan guru dalam rangka peningkatan pengetahuan, keterampilan, kemandirian, dan networking, serta keadilan (Bibi, 2015).

Media pembelajaran merupakan salah satu jenis perangkat pembelajaran yang berisi materi pelajaran dan penugasan terhadap siswa. Media pembelajaran dapat diartikan segala sesuatu yang dapat digunakan untuk menyampaikan informasi secara terencana sehingga menghasilkan suasana belajar yang kondusif dan siswa sebagai penerima informasi dapat melaksanakan proses pembelajaran yang efektif dan efisien (Munadi, 2010). Media memiliki peran yang sangat penting dalam proses pembelajaran karena dapat membantu memberikan kejelasan atas ketidakjelasan informasi yang disampaikan (Hasan \& Wijayanti, 2018). Media pembelajaran dapat dijadikan sebagai sarana penyalur informasi dari guru kepada siswa. Dengan demikian, siswa akan lebih mudah mempelajari dan memahami materi.

Anggota Kelompok Kerja Guru (KKG) Kecamatan Geger Kabupaten Bangkalan (mitra) sangat tergantung pada kegiatan pembelajaran langsung tanpa adanya media yang digunakan dalam proses pembelajaran tersebut. Banyak metode dan media pembelajaran yang masih belum digunakan oleh guru. Guru belum berupaya dalam memanfaatkan teknologi untuk membuat dan mengembangkan media pembelajaran.

Hasil diskusi pengabdi dengan mitra menyimpulkan bahwa permasalahan dasar yang dihadapi adalah kurangnya pengetahuan mitra dalam memanfaatkan teknologi komputer. Anggota KKG Kecamatan Geger masih belum mampu memanfaatkan teknologi dalam membuat dan mengembangkan media pembelajaran. Hal ini berdampak pada proses pembelajaran yang bersifat pasif dan berorintasi pada buku teks. Model pembelajaran yang demikian menjadikan siswa merasa bosan dan jenuh dalam mengikuti proses pembelajaran. Wijayanti, Hasan dan Loganathan (2018) menyatakan bahwa penggunaan media pembelajaran dapat memudahkan siswa dalam memahami materi pelajaran.

Pengembangan pembelajaran yang berbasis teknologi bagi guru di KKG Kecamatan Geger sangat diperlukan untuk mengatasi permasalahan tersebut. Perkembangan teknologi dalam pembelajaran telah mengubah cara pandang guru dalam mendapatkan informasi sebagai bekal pembelajaran (Adri, 2007). Sedangkan menurut Supriyono, Sujalwo, Sapoetra, dan Rahayu (2015), kemajuan teknologi dapat menjadi salah satu peluang bagi guru untuk meningkatkan kualitas pembelajaran. Hal ini dapat dilakukan dengan membuat media pembelajaran yang sesuai dengan perkembangan teknologi. Salah satu media yang sesuai dengan perkembangan zaman adalah media pembelajaran berbasis komputer dengan aplikasi AutoPlay. Menurut Setiawan dan Rusimamto (2017), proses pembelajaran sangat efektif bila menggunakan media AutoPlay Studio 8.

Media AutoPlay sebagai alternatif media pembelajaran audio visual dapat memotivasi siswa untuk belajar. Menurut Nisa, Wati, dan Mahardika (2019), media pembelajaran berbasis AutoPlay media studio merupakan aplikasi media pembelajaran yang mudah untuk digunakan dari segi penggunaan dan pembuatannya. Penggunaan media AutoPlay media studio menjadikan hasil belajar siswa lebih tinggi dibandingkan dengan hasil belajar siswa dengan pembelajaran langsung (Alfan \& Sulistiyo, 2015). Media AutoPlay memunculkan suara dan gambar serta animasi yang menarik. Djamarah dan Zain (2010) menyatakan bahwa media pembelajaran yang menggunakan unsur suara dan gambar lebih baik dibandingkan dengan media pembelajaran yang konvensional. Wijaya dan Rakhmawati (2015) menemukan bahwa penggunaan media pembelajaran berbasis AutoPlay yang dikembangkan memiliki hasil sebesar 91,53\% dan termasuk pada kategori yang sangat baik dan sangat efektik dalam pembelajaran. Sedangkan menurut Shubhi, Widiyanti dan Yoto (2015), penggunaan media interaktif berbasis AutoPlay media studio dapat meningkatkan motivasi belajaran siswa. Rizqi (2015) menyatakan bahwa ada perbedaan yang signifikan pemahaman siswa yang menggunakan media pembelajaran AutoPlay dan quiz creator dengan siswa yang diajar tanpa menggunakan media belajar.

Proses pembuatan media pembelajaran berbantuan komputer dengan aplikasi AutoPlay cukup mudah dan sederhana. Berdasarkan potensi yang dimiliki oleh sekolah dan guru pada KKG Kecamatan Geger, aplikasi ini dapat dibuat dengan mudah. Beberapa faktor pendukung yang merupakan potensi yang ada di KKG Kecamatan Geger adalah (1) laptop sekolah yang dapat digunakan oleh guru, (2) banyaknya tenaga pendidik yang masih tergolong dalam usia muda untuk berkreasi dalam mengembangkan media dan (3) biaya pembuatan dan pengembangan media sangat murah. 
Program kegiatan yang dikemas dalam pelatihan dan pendampingan kepada KKG Kecamatan Geger dalam membuat media pembelajaran berbantuan aplikasi komputer diyakini dapat memberikan perubahan dan sistem pengajaran kepada guru di KKG Kecamatan Geger. Menurut Ratnaningsih, Hidayat, dan Patmawati (2017), adanya pelatihan dan pendampingan bagi guru dapat meningkatkan kemampuan dalam membuat dan menggunakan media pembelajaran berbasis komputer melalui pendekatan saintifik dan memberikan motivasi kepada guru-guru untuk mempersiapkan semua perangkat pembelajaran karena guru sebagai fasilitator. Ini sependapat dengan Saepudin dan Damayani (2016) yang menyatakan bahwa pelatihan dan pendampiangan bagi guru dapat meningkatkan kapasitas pengetahuan, keterampilan, pemahaman, dan keahlian para guru dalam memilih media sebagai sumber belajar yang baik dan benar.

\section{METODE}

Kegiatan pengabdian pada masyarakat ini dilaksanakan di ruang laboratorium komputer Sekolah Tinggi Keguruan dan Ilmu Pendidikan (STKIP) PGRI Bangkalan pada bulan September 2019. Mitra dalam pengabdian ini adalah anggota KKG Kecamatan Geger Kabupaten Bangkalan yang berjumlah 20 orang.

Program pengabdian ini dilaksanakan dengan menggunakan dua metode, yaitu (1) metode pendidikan kepada masyarakat dan (2) metode substitusi ilmu pengetahuan dan teknologi (IPTEK). Kedua metode terebut dilaksanakan cara memberikan pelatihan dan pendampingan kepada guru. IPTEK yang digunakan dalam progarm ini adalah Aplikasi AutoPlay untuk membuat dan mengembangkan media pembelajaran berbantuan komputer. Evaluasi dilakukan untuk mengetahui keberhasilan kegiatan. Angket digunakan untuk mengetahui kemapuan mitra sebelum dan setelah pelaksanaan program pengabdian untuk mengeksplorasi hasil pelaksanaan pengabdian yang meliputi aspek pengetahuan, keterampilan dan penerapan media AutoPlay. Pada aspek pengetahuan dan keterampilan, keberhasilan diukur berdasarkan hasil media AutoPlay yang dibuat oleh mitra, kesesuaian materi pelajaran yang dibuat, pengembangan animasi dan tampilan media. Sedangkan untuk mengetahui penerapan media AutoPlay, instrumen angket digunakan pasca pelaksanaan pelatihan yang diisi oleh mitra. Aspek yang dimunculkan dalam angket pasca pelaksanaan pelatihan meliputi persentase penggunaan media AutoPlay dalam pembelajaran dan motivasi siswa dalam mengikuti pelajaran yang menggunakan media AutoPlay. Data disajikan dalam bentuk persentase perubahan yang terjadi sebelum dan setelah pelaksanaan program pengabdian.

\section{HASIL DAN PEMBAHASAN}

Pelatihan tentang pembuatan media pembelajaran interaktif berbasis AutoPlay dilaksanakan sesuai waktu yang telah ditentukan. Peserta yang hadir sesuai dengan sasaran awal yaitu sebanyak 20 orang guru anggota KKG Kecamatan Geger (Gambar 1). Program pengabdian ini memberikan banyak manfaat bagi mitra, diantaranya adalah produk berupa media pembelajaran interaktif berbasis AutoPlay (Gambar 2).

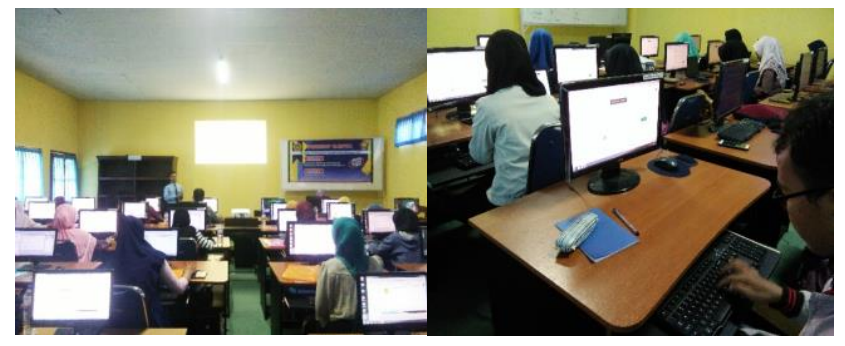

Gambar 1 Penyajian materi pengabdian bagi KKG Kecamatan Geger Kabupaten Bangkalan

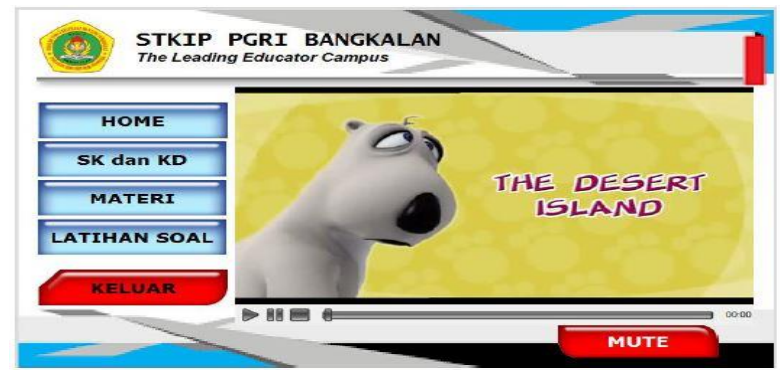

Gambar 2 Tampilan hasil pengembangan media AutoPlay 
Langkah awal yang dilakukan adalah menginstal aplikasi AutoPlay di komputer laboratorium. Mitra langsung dapat mempraktikkan pembuatan media interaktif berbasis AutoPlay dengan mengikuti arahan dan bimbingan instruktur (Gambar 3). Mitra sangat antusias untuk mengikuti kegiatan tersebut. Peserta memiliki keingintahuan dalam membuat media pembelajaran berbasis komputer. Mitra ingin menjadikan proses pembelajaran di sekolah semakin menarik dengan adanya media pembelajaran.

Kegiatan selanjutnya adalah pendampingan dan pembimbingan membuat media pembelajaran berbasis AutoPlay. Mitra dipandu untuk menggunakan aplikasi AutoPlay yang telah diinstal. Mitra mencoba membuat new project pada AutoPlay sebagai latihan membuat media pembelajaran pada tahap pendampingan (Gambar 4).

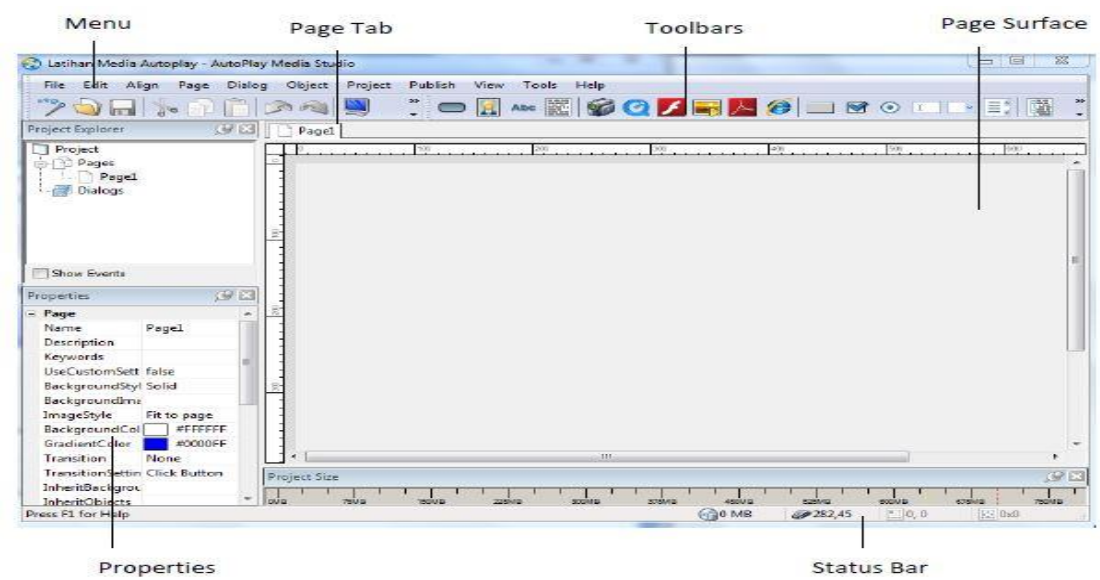

Gambar 3 Lembar kerja dalam memulai membuat media pembelajaran berbasis AutoPlay

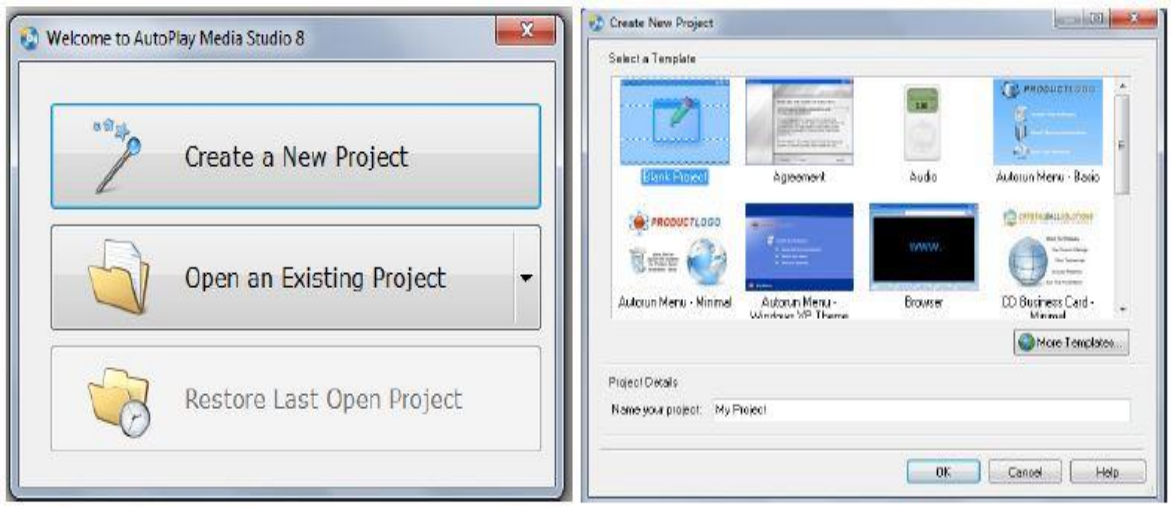

Gambar 4. Tampilan menu media interaktif berbasis AutoPlay

Setelah semua kegiatan pendampingan dan pembingan diikuti oleh mitra, produk akhir berupa media pembelajaran berbasis AutoPlay disimpan pada folder masing-masing mitra. Selanjutnya berkas tersebut dijadikan sebagai media belajar untuk dikembangkan saat mitra bertugas di sekolah masing-masing (Gambar 5).

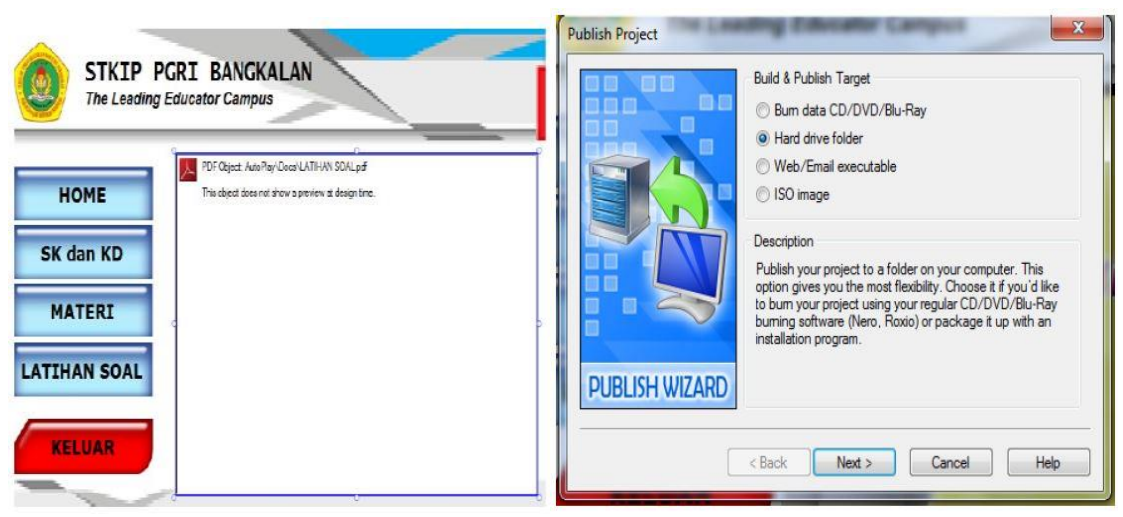

Gambar 5. Tampilan produk media inetraktif berbasis AutoPlay 
Hasil evaluasi menunjukkan bahwa mitra mengalami banyak perubahan dalam membuat media pembelajaran berbasis komputer. Angket digunakan untuk mengetahui hasil pelaksanaan pengabdian yang meliputi aspek pengetahuan dan keterampilan, penerapan media AutoPlay. Mitra menjadi tahu dan terampil dalam membuat media pembelajaran. Sebanyak $90 \%$ dari 20 orang mitra telah mengalami perubahan pengetahuan menjadi lebih baik. Mereka mengalami peningkatan pengetahuan dan terampil dalam membuat media pembelajaran berbasis AutoPlay. Sebanyak 80\% mitra telah mampu mengimplementasikan media berbasis AutoPlay dalam pembelajaran di sekolah (Gambar 6). Hal ini senada dengan Hasan (2018) yang menyatakan bahwa adanya perlakuan yang maksimal dapat memberikan hasil yang baik.

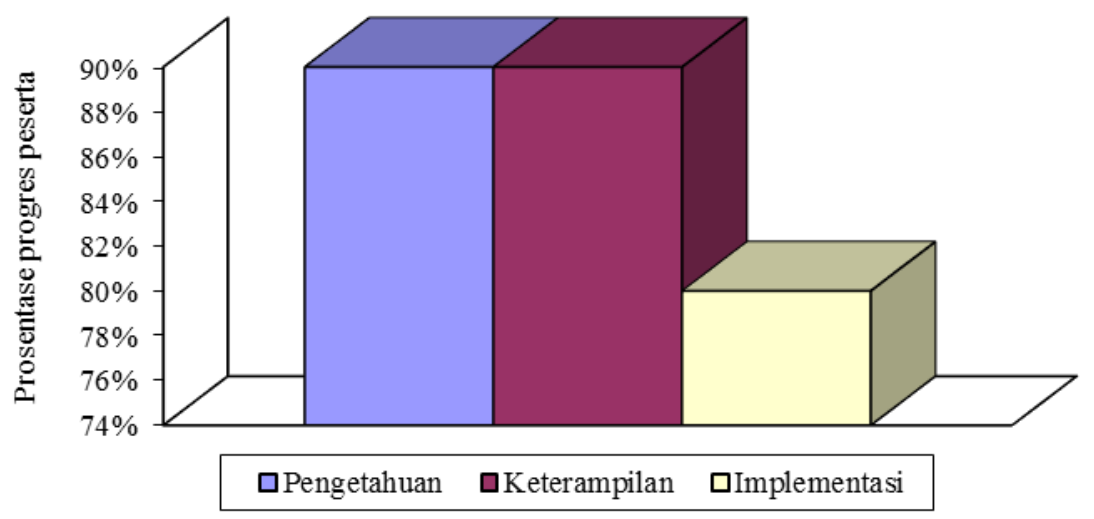

Gambar 6. Progres kemampuan peserta

Pengetahuan dan keterampilan diukur juga berdasarkan hasil media AutoPlay yang dibuat oleh mita, kesesuaian materi yang dibuat, pengembangan animasi dan tampilan media. Aspek yang dimunculkan dalam angket pasca pelaksanaan meliputi persentase penggunaan media AutoPlay dalam pelajaran (Tabel 1 dan Tabel 2).

Tabel 1. Penggunaan media pembelarajan sebelum pelatihan

\begin{tabular}{lcccc}
\hline \multirow{2}{*}{ Subjek } & \multicolumn{2}{c}{ Penggunaan media dalam pembelajaran } & \multicolumn{2}{c}{ Penggunaan media AutoPlay dalam } \\
& \multicolumn{2}{c}{ pembelajaran } \\
\hline \multirow{2}{*}{20 Orang Guru } & Belum & Sudah & Belum & Sudah \\
& $75 \%$ & $25 \%$ & $100 \%$ & $0 \%$ \\
\hline
\end{tabular}

Tabel 2. Kemampuan guru dalam pembuatan media AutoPlay dan penggunaannya setelah pelaksanaan program pengabdian

\begin{tabular}{|c|c|c|c|c|}
\hline Subjek & Kemampuan I & dia AutoF & \multicolumn{2}{|c|}{ Penggunaan Media AutoPlay } \\
\hline \multirow{2}{*}{20 Orang Guru } & Belum & Mampu & Belum & Sudah \\
\hline & $10 \%$ & $90 \%$ & $20 \%$ & $80 \%$ \\
\hline
\end{tabular}

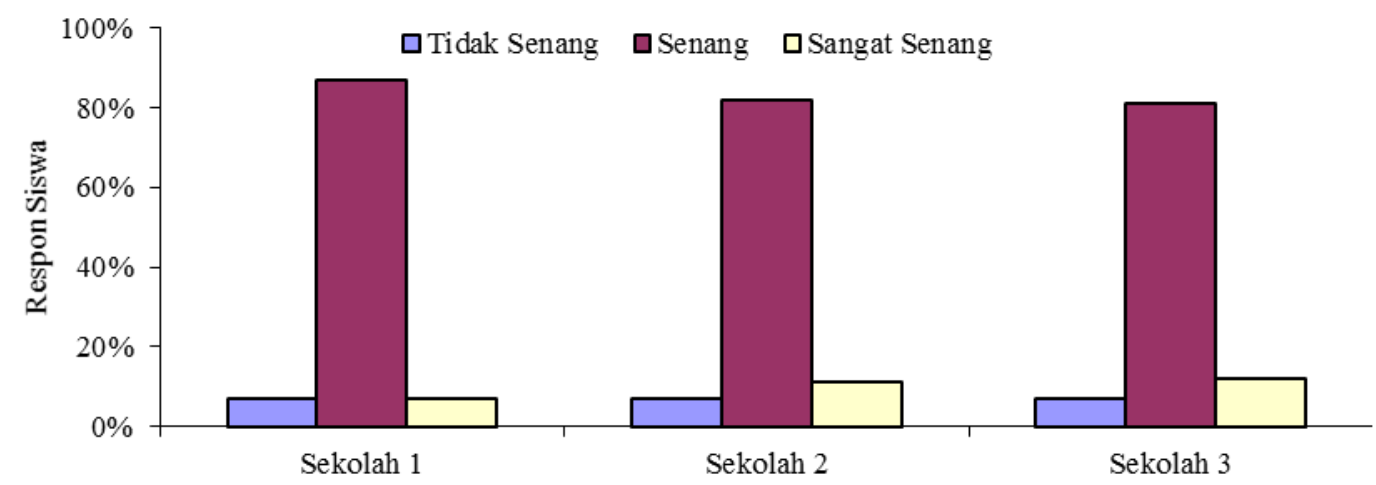

Gambar 7. Persentase respon siswa terhadap penggunaan media AutoPlay 
Motivasi siswa dalam mengikuti pelajaran yang menggunakan media AutoPlay juga diamati. Yang menarik untuk ditelusuri lebih lanjut adalah adanya 7\% siswa dari tiap sekolah yang tidak senang dengan pembelajaran yang menggunakan media AutoPlay. Siswa yang sangat senang berkisar 7\% sampai 12\%. Rata-rata 83\% siswa di 3 sekolah mitra merasa senang dan termotivasi belajar jika pembelajaran menggunakan media AutoPlay (Gambar 7). Dengan demikian, penggunaan media AutoPlay dalam pembelajaran mampu menjadikan siswa senang dan termotivasi untuk belajar. Hal itu terjadi karena media AutoPlay sesuai dengan perkembangan jaman dan sesuai dengan karakteristik siswa. Menurut Sudjana dan Rivai (2011), ada beberapa kriteria yang harus diperhatikan oleh guru dalam memilih media yang akan digunakan dalam proses pembelajaran yaitu kesusuaian dengan tujuan pembelajaran, kesesuaian terhadap isi materi, kemudahan untuk membuat media, waktu penggunaan media dan kesesuaian kemampuan berpikir peserta didik. Pengembangan media pembelajaran harus disesuaikan dengan perkembangan jaman dan juga disesuaikan dengan karakteristik siswa. Salah satunya adalah media pembelajaran berbantuan komputer dengan aplikasi AutoPlay.

Beberapa kendala yang dihadapi dalam pelatihan dan pendampingan adalah (1) kemampuan dasar dari mitra yang sangat kurang dalam mengoperasikan komputer, (2) pengembangan lanjutan dari media AutoPlay yang sudah dibuat karena hanya $45 \%$ dari seluruh mitra yang mempunyai laptop.

\section{KESIMPULAN}

Program pengabdian kepada masyarakat ini memberikan banyak manfaat dalam peningkatan kualitas pendidikan di Kecamatan Geger Kabupaten Bangkalan. Peningkatan pengetahuan dan keterampilan guru dalam membuat media pembelajaran yang kreatif dan interaktif mencapai $90 \%$ dari 20 orang guru. Sebanyak $90 \%$ media yang dibuat sudah memenuhi kriteria sesuai isi materi, animasi, tampilan dan penggunaannya. Rerata $80 \%$ guru mitra mampu mengimplementasikan media AutoPlay dalam proses pembelajaran. Selain itu, siswa semakin termotivasi dalam belajar.

\section{UCAPAN TERIMA KASIH}

Pelaksaan program ini didukung penuh oleh Lembaga Penelitian dan Pengabdian Kepada Masyarakat STKIP PGRI Bangkalan. Dukungan yang diberikan berupa biaya pengabdian pada masyarakat Tahun Anggaran 2019 dengan nomor kontrak 067/C1/H/IX/2019.

\section{DAFTAR PUSTAKA}

Adri, M. (2007). Pemanfaatan internet sebagai sumber pembelajaran. Prosiding Semiloka Pengembangan Model Pembelajaran Berbasis Teknologi Informasi (hal. 1-11). Padang, Indonesia.

Alfan, M., \& Sulistiyo, E. (2015). Perbandingan media pembelajaran (AutoPlay Media Studio) sebagai alat bantu pembelajaran memperbaiki CD Player siswa Kelas XI di SMK Negeri 3 Surabaya. Jurnal Pendidikan Teknik Elektro, 4(1), 39-47.

Bibi, S. (2015). Efektivitas model blended learning terhadap motivasi dan tingkat pemahaman mahasiswa mata kuliah algoritma dan pemrograman. Jurnal Pendidikan, 5(1), 74-80.

Djamarah. S.B \& Zain, A. (2010). Strategi belajar mengajar. Jakarta, Indonesia: Rineka Cipta.

Hasan, B., \& Wijayanti, R. (2018). Efektifitas penggunaan media Comic Math berbasis Whiteboard Animation dalam pelajaran matematika. Apotema: Jurnal Program Studi Pendidikan Matematika, 4(2), 44-50.

Hasan, B. (2018). Manajemen produksi usaha lampu hias kreasi bamboo di Kabupaten Bangkalan Propinsi Jawa Timur. JAST: Jurnal Aplikasi Sains dan Teknologi, 2(2), 88-94.

Munadi, Y. (2010). Media Pembelajaran. Jakarta, Indonesia: Gaung Persada Press

Nisa, K., Wati, M., \& Mahardika, A. I. (2019). Pengembangan media pembelajaran berbantuan aplikasi AutoPlay Media Studio pada pokok bahasan fluida dinamis di SMA. Jurnal Ilmiah Pendidikan Fisika, l(1), 13-23.

Ratnaningsih, N., Hidayat, E., \& Patmawati, H. (2017). Pembuatan dan penggunaan media pembelajaran berbasis komputer melalui pendekatan saintifik bagi guru-guru. Jurnal Pengabdian Siliwangi, 3(1), 54-62.

Rizqi, M. B. (2015). Pengembangan media pembelajaran AutoPlay dan quiz creator pada mata pelajaran IPS materi penjajahan Belanda untuk meningkatkan pemahaman siswa kelas V di SDI Al-Faqih Baran Sukoanyar Pakis 
Malang [Disertasi]. Universitas Islam Negeri Maulana Malik Ibrahim.

Saepudin, E., \& Damayani, N. A. (2016). Literasi media bagi guru PAUD Di Kecamatan Cicalengka. Jurnal Dharmakarya, 5(1), 38-43.

Setiawan, W. A., \& Rusimamto, P. W. (2017). Pengembangan media pembelajaran menggunakan software AutoPlay Media Studio 8 pada mata pelajaran perekayasaan sistem radio dan televisi Kelas XI AV di SMK Negeri 1 Sidoarjo. Jurnal Pendidikan Teknik Elektro, 1(6), 85-91.

Shubhi, M. L. R., Widiyanti, W., \& Yoto, Y. (2015). Pengembangan media pembelajaran interaktif berbasis aplikasi AutoPlay Media Studio 8 pada materi turbin air Program Keahlian Teknik Pemesinan Kelas X di SMK Nasional Malang. Jurnal Pendidikan Profesional, 4(1), 83-91.

Sudjana, N \& Rivai, A. 2011. Media pembelajaran. Bandung, Indonesia: Sinar Baru Algesindo.

Supriyono, H., Sujalwo, S., Sapoetra, A., \& Rahayu, E. T. (2015). Pelatihan pengembangan media pembelajaran berbasis web bagi guru SMP dan SMA Muhammadiyah Kartasura. Warta LPM, 18(2), 98-109.

Wijaya, I., \& Rakhmawati, L. (2015). Pengembangan media pembelajaran AutoPlay media studio pada mata pelajaran perekayasaan sistem audio di SMK Negeri 3 Surabaya. Jurnal Pendidikan Teknik Elektro, 4(3), 957-963.

Wijayanti, R., Hasan, B., \& Loganathan, R. K. (2018). Media comic math berbasis whiteboard annimation dalam pelajaran matematika. Jurnal Riset Pendidikan Matematika, 5(1), 53-63. 